\title{
LAUFERICA
}

\section{ЕіІані Імото*}

On the streets of Iran boiled sugar beets sell well. The sugar beet (Beta vulgaris) is called lab $\bar{u}$ or lap $\bar{u}$ in Persian. Pers. labu or lapu is derived from Pahl. *lapūy, *lapūg or *lapük. Pahl. *lapük is derived from O Pers. *läpüka-.

Pers. labū designates a sugar beet and is akin to Gk. rhapys and Lat. räpum, but the latters designate turnip. Fr. rave, Germ. Rübe and Eng. rape are also of the same group. According to Hofmann and Pokorny(1) these European words are of an IE root borrowed from an unknown source. Pers. lab $\bar{u}$ should have been included in this group.

Chinese people indicated a turnip by a word 蘿䕎. It was pronounced la-puk during the Sui and T'ang dynasties, even down to the Han dynasty. These two Chinese characters are not ideograms except pointing plant or grass, but only indicate sounds. It is obvious that the compound of these two characters is not Chinese in origin but of a foreign origin. Another kinds of characters which have almost the same sounds are 蘆䓳, 萊䓳, 蘿获 and so on.(2) They have the same meaning of a turnip. Chinese la-puk does not designate a sugar beet, but designates a turnip. If the meaning of the ancient Iranian word was not only a beet but also a turnip, that is probable, the Chinese were sure to borrow the word and the thing from the Iranian.

Among Iranian people when Nou Rūz comes near, they prepare the Haft Sin. The Haft Sin is seven kinds of plants, vegetables or foods, each word of which begins with $s$. And these plants and vegetables are partly wild and partly cultivated. In the countries of the Far East, on the 7th day of January they used to make gruel with seven kinds of wild and cultivated herbs and vegetables. Japanese people have called it the Nana-kusa-gayu (Seven-kindgruel), in which the turnip was included. At the Persian Nou Rūz (New Year), however, the turnip is not included in the Haft Sin; Persian turnip, salgam does not begin with $s$ but $\zeta$.

The purpose of eating these seven kinds of foods at the New Year is to make people go back to the primordial world and take spirits of foods. Chinese

* Professor, Osaka Univesity of Foreign Studies. 
people have a tradition to gnaw on a turnip at the beginning of spring. It is called jiao-chun 咬春 or gnawing of spring. People offered a turnip to the god and then ate the offering itself as the body of the god.

As the word 蘿葍 and the turnip itself were of foreign origin, eating of the spirit of spring at the change of the year was also of foreign origin; it seems that people of the Far East borrowed the custom from West Asia.

Persian bāda means wine. It is derived from Middle Persian (Pahl.) bādag or bātak. M Parthian vädag or vātak had the same meaning. O Pers. bātu- in bätu-gara- 'drinking cup' is 'wine'. Laufer identified 葡萄 'grape, vine' with Pers. bāda. His Chinese sound was p'u-t'ao, *bu-daw. He supposed that Old Iranian *budāwa- was composed of a stem buda- and a suffix wa- or awa-, and buda- may be connected with Pers. bāda. ${ }^{(3)}$

Chinese sound of 葡萄 in the early and middle stage, however, was bwagdag, ${ }^{(4)}$ which certainly represented bwädag, namely Pahl. bãdag or Parth. vädag. Japanese sound of 葡萄 is budo <budau. It is based on a developed form of bwag-dag; bwag developed into bwaw, bu, and dag into daw. 葡萄 bwag-dag $>$ bwädag, therefore, does not represent *budaw, as Laufer remarked, but transliterated Middle Persian or Parthian words.

In O Pers. bātu- we may see a kind of M Pers. form of bātag, bātak; bātag became bātaw, bātu. Part of the syntax of the identical inscription of four silver dishes made in the royal house of Artaxerxes became corrupt into M Iranian stage, and so the popular pronunciation also became already Middle Iranian.

According to Herodotus (1. 108), when Mandane, daughter of the Median king Astyages, was married to Cambyses, Astyages dreamed that from her pudenda a vine tree grew up and covered over Asia. The same kind of story is found in Japan. The mother of Fujiwara-no Kamatari, the ancester of the Fujiwara family, one of the most powerful families of Japan, dreamed, before delivering her son, that a wisteria vine grew up from her pudenda and covered all over Japan (Tounomine Engi『多武峯縁起』).

From these stories it is clear that the vine tree represented the tree of life and the tree itself represented the ancestral hero. Wine was regarded as the blood of the ancester or god; Christianity later on regarded wine as the blood of Christ.

Persophone was carried away by Pluto into the underworld, the Hades. 
There she ate the pomegranate, the food of the dead, and became an inhabitant of the Hades. Demeter, her mother, managed to settle with Pluto that Persephone should live part of the year on the ground and the rest of the year under the ground.

Pers. anār 'pomegranate' is derived from M Iran. närak which is derived from O Iran. *näraka-. The meaning of O Iran. *näraka-, which is cognate with Skt. näraka-, was 'belonging to the naraka, the Hades.' It was a food of the dead.

According to Lo-yang chia-lan-chi『洛陽伽藍記』 of the 6th century of our era, in front of the tower of the Buddhist Temple Po-ma-ssŭ 白馬寺 there stood a vine tree and a pomegranate tree. When fruits became ripe the emperor himself came there to pick them from the trees (Chapter 4). In this book the pomegranate is transcribed by 茶林 dag-lim, da-lim, which corresponds to Skt. dâlima- 'pomegranate'. The pomegranate is represented by 塗林 dag-lim too. Laufer interpreted 塗林 $t^{\circ} u$-lin as ${ }^{*}$ dulim and did not see dalim in 鋈林.(5) It seems indisputable that 塗林 is a transcription of dālim. It is interesting that both the vine and the pomegranate tree stand at the entrance of the Buddhist Temple. Both trees were regarded as the tree of life on the threshold of death and life.

The pomegranate was believed to be a food or a gift to the bride as well as to the dead. It was a fruit of fertility and resurrection. As Laufer remarked, among the Arabs, the bride, when dismounting before the tent of the bridegroom, received a pomegranate which she smashed on the threshold, and then flung the seeds into the interior of the tent.(6) A Chinese custom to give a pomegranate to the bride is to symbolize her fertility.

\section{Notes}

(1) J. B. Hofmann, Etymologisches Wörterbuch des Griechischen, München, 1949.

J. Pokorny, Indogermanisches Etymologisches Wörterbuch, Bern, 1959.

(2) TODOO Akiyasu (ed.), Gakken Kan-Wa Dai Jiten, Gakushū-Kenkyū-sha, 1978. （藤 堂明保編『学研 漢和大字典』学習研究社, 昭和53年).

(3) B. Laufer, Sino-Iranica, Chicago, 1919, p. 225.

(4) TŌDO, op. cit., pp. 1118 and 1114.

(5) Laufer, op. cit., pp. 282-3.

(6) Laufer, op. cit., p. 287. 